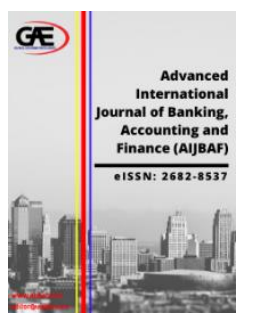

\author{
ADVANCED INTERNATIONAL JOURNAL OF \\ BANKING, ACCOUNTING AND FINANCE \\ (AIJBAF) \\ www.aijbaf.com
}

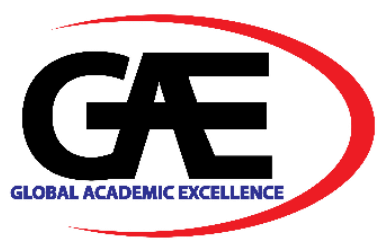

\title{
SUKUK: POTENTIALS FOR INFRASTRUCTURAL DEVELOPMENT IN NIGERIA
}

\author{
Jubril A. Salaudeen ${ }^{{ }^{*}}$ \\ $1 \quad$ Nungu Business School - Nigeria \\ Email: jubrilsalaudeen@gmail.com \\ Tel: +234 8023400331 \\ * Corresponding Author
}

\section{Article Info:}

Article history:

Received date: 30.03 .2021

Revised date: 14.04 .2021

Accepted date: 01.06.2021

Published date: 15.06 .2021

\section{To cite this document:}

Salaudeen, J. A. (2021). Sukuk: Potential for Infrastructural Development in Nigeria. Advanced International Journal of Banking, Accounting, and Finance, 3 (7), 104113.

\section{DOI: $10.35631 / A I J B A F .37009$}

This work is licensed under $\underline{\text { CC BY } 4.0}$

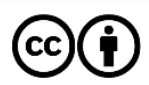

\begin{abstract}
:
The growth of any economy in the world will happen on the back of the needed infrastructural facilities. And to build the needed infrastructures for national development requires a lot of money and time. There have been incessant concerns of the citizenry on the present level of infrastructural neglect and decay in Nigeria. The infrastructural decay in Nigeria ranks very high when compared to the national resources to the availability and quality of the needed infrastructure. The availability of needed infrastructures will enhance ingenuity, novelty, employment, self-confidence, wealth creation, and social security. However, it is wretched to note that the dire infrastructure in Nigeria is in a bad state thereby creating an evolving crisis. The inability of the government of Nigeria to maintain and endure her perilous infrastructure such as; road rails and pipelines network, the micro small and medium enterprises will require developed and scalable transportation infrastructure ( Land, Air, and Water), Electricity energy ( power for industrial and domestic use), Educational infrastructure ( Schools, Research and instructional materials), Health infrastructure ( Hospital, trained personnel, and Equipment), Security infrastructure ( Police, Military and Para-military). This study aims to explicate the potential of Sukuk as an alternative and sustainable financial vehicle for financing infrastructural development in Nigeria. The study is library-based and analytical and evaluation approaches are used to explore related librarybased data on the causes and effects of infrastructural development in Nigeria. The study investigates and describes how the Nigerian government can utilize the potentials of Sukuk investment for infrastructural development across the nation.
\end{abstract}

Keywords:

Sukuk, Infrastructure, Development, Nigeria, Potentials, Government 


\section{Introduction}

Infrastructural decay in every sector of the Nigeria economy are major factors responsible for poor development across the entire states of the nation. The government at Federal and State levels seems concerned as much as the citizenry about the challenges of infrastructural facilities in several public institutions (Ogbuagu, Ubi, \& Effiom, 2014).

One of the factors that has contributed to the development crises in Nigeria, is the infrastructure decay. The problem of infrastructural decay or near absent in some sectors has manifested in the form of high level of unemployment, poverty, frustration, desperation, criminality as well as relocation and migration from Nigeria to Europe, America, Canada and other parts of the world. According to Eke, (2011: 39) who assert that; It is not a matter of rhetoric or polemics that basic infrastructure in Nigeria is in a semi-comatose state, and from colonial times up till the present day, the issues of infrastructural development have remained on the lips of successive administrations with no visible indication of accomplishment (Rufus, 2017).

On March 27, 2019 Okechukwu Enelamah, the Nigeria minister for trade and investment, announced that the Federal government of Nigeria, plans to accelerate infrastructure investment as a fundamental part of efforts to increase revenue generation on infrastructure spending from \$10bn-to-\$20bn over the spans of five to 10 years. Enelamah said during a press briefing (Oxford Business Group, 2019). Zainab Ahmed, the Nigerian minister of finance, told a Senate hearing that, while state revenue flows had improved over the past year, challenges in generating earnings remained, necessitating the tapping of bond markets to support infrastructure development. She further said:

"We intend to borrow both locally and internationally, improve on our local borrowing, introduce an infrastructure bond, and to identify new and enhance existing revenue streams,"

The government is looking at an even division between globally and locally raised debt, Ahmed said, with the focus being on concessionary long-term loans. While the minister did not set a value on the proposed bond issuances or other government borrowing, the 2019 budget proposed in December 2019, flagged overall debt issuances of N1.7trn ( $\$ 4.7 \mathrm{bn})$, half of which will be denominated in foreign currencies(Zainab Ahmad, 2019).

Speaking before the Parliament's Committee on Works in late March 2019, Babatunde Fashola, the minister of power, works and housing, also proposed floating a N10trn (\$27.8bn) bond to be used on road, rail, aviation and maritime development, noting that critical infrastructure would encourage economic development and in turn increase government revenue. Considering the role of critical infrastructure in the development of Nigeria, successive governments of Nigeria from colonial to present has given little or no attention to it. This view is also captured in the words of Ihembe, (2011: 504) when he asserted that: "Infrastructure as a critical form of development plays an important role in any country or region or state. Seriously it constitutes the hub upon which socioeconomic aspects of society revolve."(Oxford Business Group, 2019)

As it will be expected, improvement upon infrastructural development is a key to raise the quality and standard of living in the life of its citizens. For instance, availability of critical infrastructures like; power, quality health care system, quality educational system, water, rail 
Volume 3 Issue 7 (June 2021) PP. 104-113

DOI 10.35631/AIJBAF.37009

transport system with good road network, good service sector, and its protection and maintenance will bring about good life to Nigerians.

Although, comments and reports from related policy makers shows the government intent and commitments to activate the Nigeria infrastructures, It has been observe that Nigeria cannot build an agile infrastructure at the back of fluctuating global oil price, to move the envelop the need to identify and priorities the infrastructure plus decide which financial instruments to deploy in achieving our needed objectives (Lagos Chamber of Commerce \& Industry, 2016).

This paper tends to access and evaluate the country's critical infrastructural decay and proffer solutions building new and repairing existing infrastructures with the aid of the Sukuk. A comparative analysis of Nigeria and other countries, who started their national development plans at about the same time as Nigeria will be considered to identify the missing link and its prospects. The researcher will make recommendations where necessary. Infrastructure facilities are demanded for what they will help in producing. whether in developed or less developed societies, the capacity and capability necessary for business growth stem from the acquisition of science and technology, culture and the availability of enabling infrastructure. The enabling infrastructures are the major factors which must exist to allow private enterprises to operate and grow.

Similarly, the researcher proposes Sukuk as a superior infrastructural funding instrument as against loans and other instruments that are characterized with hug leakages and unnecessary terms and interest. Sukuk: Like its conventional counterpart, the bond has come a long way in Islamic finance. The evolution of Sukuk transactions not only includes continuously innovative applications of various Islamic contracts but also a host of structural elements to enhance the credit standing of such transactions. "Credit enhancement" has become a notable feature in various bond structures, with the main objective of mitigating credit risk. In its most basic form, such credit enhancement - or credit support - represents a kind of guarantee, either through a third party or otherwise, a purchase-undertaking ("PU"), or a letter of support. The latter may come from a parent company, acknowledging a subsidiary's debt and its intention of providing financial support. The provision of credit enhancement by the obligor is a key factor in credit assessments of the Sukuk; this applies to both Islamic and conventional securities. Nigeria has issued two sovereign Sukuks of 100bn each. Going by the successes recorded in the previous issues and the deployment of the credit towards road infrastructure, it is important to outline the gains recorded and match same with the infrastructural gap with the view of developing the needed infrastructures.

\section{Origin of Sukuk}

Historical records allude to the creation of sukuk as a borrowing instrument that Islamic legal scholars in the Turkish Empire helped to design for public financing when the emperor needed to borrow large sums of money for reconstruction after the devastation of the empire after five crusades that ended in $1285 \mathrm{CE}$. The innovation of fund-raising consistent with Islamic ethics of borrowing differed considerably from Christian practices at that time, which were based on Babylonian and Greco-Roman laws.

A financial contract must have the following characteristics under the Islamic participatory finance principles of borrowing and funding. Ownership and control contracts must be based on profit sharing by participating in the risk of the project so that the profit accrues to lenders Copyright $\odot$ GLOBAL ACADEMIC EXCELLENCE (M) SDN BHD - All rights reserved 
Volume 3 Issue 7 (June 2021) PP. 104-113

DOI 10.35631/AIJBAF.37009

after the fund is used for the project. The outcome of such funding is the profit earned, which is shared in proportion by the financier and the business. The important issue is that it is a shared arrangement even though the sukuk is a borrowing instrument for a limited period. One brings the capital and the other entrepreneurship to make things useful for the society under a joint arrangement. Other Sukuk structures on Ijarah (leasing) exists and the contracts have grown to take different forms in structure and size in funding.

\section{Development of Sukuk as Modern Financial Instruments}

The development of sukuk have passed through four main stages, first; the first experiment of sukuk after the establishment of Bank Islam Malaysia Bhd in 1983 as the first Islamic bank in the country. The acceptance by people and regulatory support by the government for Bank Islam motivated issuance of sukuk. The first sukuk was issued 1990, it was a 125 million Malaysian Ringgit sukuk issuance by Shell MDS Sdn Bhd (Khiyar, 2020).

The second phase of sukuk development was witnessed with the innovative idea of Dr Sami hamūd on the application of Sanadāt Muqāradah (bond financing) which is based on the muḍārabah structure as an alternative to replace conventional bond . On the third phase, Fiqh Academy of Organisation of islamic countries validate sukuk investment in 1988. The Organisation of the Islamic Conference International Islamic Fiqh Academy (the Fiqh Academy) approved sukuk trading and paved the way for the introduction of sukuk as a capital markets instrument. The fourth phase was marked by Accounting and Auditing Organization for Islamic Financial Institutions(AAOIFI) in 2004 after issuing Shariah standards for Islamic finance products and practices including sukuk(Ali, 2005). The AAOIFI defines Sukuk as a certificate of equal value representing undivided shares in ownership of tangible assets, usufrust and services or ( in the ownership of) the assets of projects or special investment activity.

\section{Research Type}

This research work is purely based on desk research. Desk research is a research type that uses secondary research. Here the researcher review what other people have done. Since desk research is not about collecting data. The researcher role is limited to carrying out desk research by reviewing previous research findings to gain a broad understanding of the potentials of employing Sukuk for infrastructural development in Nigeria.

\section{Why Do Desk Research?}

Due to the arrays of comments, emotions, discussions and the controversies surrounding the use of Sukuk in Nigeria and the near dismissal stage of Public infrastructures, the researcher has employ desk research because it is the quickest and cheapest way to understand the domain.

According to David Travis (Think Like a UX Researcher 1989) Carrying out desk research is a critical first step, for at least three reasons:

If you don't know what has gone before, you won't know when you've discovered something new. You'll sound credible when you get face-to-face with users and stakeholders. If you've not done this "due diligence", you'll ask dumb or irrelevant questions and may find your participants cut your sessions short. Failing to do preparatory research is disrespectful of your participants' time. You may get less than an hour with a user of your system. Do you really 
Volume 3 Issue 7 (June 2021) PP. 104-113

DOI 10.35631/AIJBAF.37009

want to waste half that time understanding the domain issues that you could have covered elsewhere?

In the light of the above, the researcher will like to put forward the following research questions:

1. To what extent does infrastructure decay account for high level of poverty and unemployment in Nigeria?

2. Are there way(s) that the sukuk can be deployed for sustainable infrastructure development in Nigeria?

3. To what extent does poor educational infrastructure account for the ill in the economy?

\section{Influence of Infrastructure on Poverty and Unemployment in Nigeria}

Infrastructures are mainstay of every national economy. The basic infrastructures in every modern society includes transportation system, communication network, electricity, road, portable water, sewage systems etc. (Popova, 2013). Infrastructural development usually requires huge capital and as a result many governments of the underdeveloped and developing nations are confronted with the challenges of accessing liquidity to finance infrastructural projects. The role of infrastructures in every sectors of the economy indicates the extent it influences level of poverty and unemployment especially in Nigeria. Poverty and Unemployment are common phenomenon in Nigeria among the citizens (Chete, Adeoti, Adeyinka, \& Ogundele, 2016). Infrastructures development in Nigeria is one of the mechanisms to alleviate poverty and reduce unemployment. Creating more public facilities such as schools, hospitals and modern transportation system will provide jobs for the people and reduce poverty. Also, proper management and maintenance of the existing infrastructures guarantees continuous and sustainable labor forces in the existing infrastructure, for instance, proper maintenance of the public hospital will protect those that needed medical facilities on one side and job security for the medical staff on the other hand (Agbigbe, 2016).

Although political instability and incessant changes in government is one of the factors responsible lack of adequate infrastructure in a number of developing countries which include Nigeria, poor management of the existing facilities have led to increase socio-economic challenges across Nigeria. However, Poverty in economic term is the situation of low income and the inability to procure necessities for an individual and average household such feeding, education, health and social security. Poverty is apparent and high vulnerability of the citizen to health and decease, crime, violence and other disasters. Unemployment on the other is a potential agent of social inequality risk (Ogun, 2010). The unemployment population in Nigeria indicates insufficient infrastructures to cater for the need of the people. The limited and inadequate education facilities have continuously reduced the number of labor force in educational institutions. It is important to note that despite the political will of the various Nigeria arms of the government, records have shown that its state resources and proposed yearly budget may not be able to cater of the needed infrastructure in the country (Adenike, 2018). Meanwhile, there is a dire need for capital intensive financing mechanism such as sukuk to address the need of the nation.

\section{The Introduction to Sukuk in Nigeria}

Osun State Sukuk was the first Sukuk issued in Nigeria. The Osun Sukuk was issued in 2013. According to the governor of Osun state, Rauf Aregbesola. the proceeds from the sukuk were 
Volume 3 Issue 7 (June 2021) PP. 104-113

DOI 10.35631/AIJBAF.37009

ultimately used to build ten schools - three in Osogbo the state capital, and one each in Ilaoragun, Ikurun, Iwo, Ilesa, Ife, Ikire, and Ejigbo - so the underlying income-generating assets were the schools.

In particular, the Osun sukuk was structured along the Sukuk Ijarah: the state government set up an Special Purpose Vehicle (SPV) called the Osun State Sukuk Company. The SPV owned the schools and sold individual rights of ownership to the sukuk holders.

The SPV then turned around and leased the schools to the state government, and earned rent from this agreement, which was then used to pay the sukuk holders. Once the lease expired at the end of the 7-year period, the state government bought the schools outright and these funds are returned to the sukuk holders as principal.

The investors got their principal plus rentals and the lesson learned can be migrated to future issues by state governments and professional's concern. The Osun state government was able to build twenty-seven (27) schools according to the governor.

The Osun Sukuk was novel, however Sudan and Gambia launched sukuk from the late 2000s, mostly as a tool of central bank reserve management. Abdurerahman Jamal Yesuf ( Islamic Economics and Finance in Sudan : IKRAM Report 4, December 2017 )

It was only in the wake of the Osun State issue that Nigeria's Securities \& Exchange Commission (SEC) introduced rules that created a framework for selling and investing in sukuk. The implication is that the Osun Sukuk did not make the secondary market for trading. The Osun State sale proved to be an icebreaker in Nigeria. There after the Federal government of Nigeria has issued two sovereign sukuks.

Senegal thrust off events with a 100 billion CFA franc 4-year sukuk in 2014, and Côte d'Ivoire upped the ante with consecutive 5-year and 7-year sukuk sales in 2015 and 2016, both worth 150 billion CFA franc.

Meanwhile, South Africa became the first African country to launch a dollar-denominated sukuk when it sold a 6-year \$500 million sukuk in 2014. The Federal Government of Nigeria (FGN) sold a 100 billion 7-year sukuk to finance twenty-five (25) major roads in the country. With the success achieved on the first issue, the FGN quickly issued another round of 100 billion 7-year issue in 2018. By this time the Federal government of Nigeria has put in-placed the legal and regulatory framework through the Debt Management Office (DMO) of Nigeria.

\section{The Role of Sukuk in Achieving Sustainable Infrastructure Development in Nigeria}

Sukuk investment is an important Islamic finance liquidity instrument to create fund for the owner of underlying asset to fund new projects either as government through sovereign sukuk or corporate sukuk for cooperation and limited liability companies. Sukuk investment has several kinds of structures such as Ijārah Sukuk (Ownership in leased asset certificates), sukuk ,Murābaḥah Șukūk (Purchasing Goods Certificates), Salam Sukuk (Forward Sale Certificates), Mushārakah Sukuk (partnership Certificates), Muḍārabah Sukuk (Profit Sharing Certificates)Istișnā' Sukuk (Manufacturing), Wakālah Sukuk (Investment agency. The sukuk structures are Islamic alternative financing for new projects by reducing risk for the investment 
based on the philosophy of underlying asset which represent the ownership of the investors (Ahmed, Lane, \& Dh, 2018; Beebee Salma Sairally et all , 2017; Busari, 2018).

In many cases, lack of public infrastructure in the country is as a result unavailable huge amount of money to fund capital projects. Sukuk investment is one of sustainable modern mechanism for financing infrastructural project with less worry about investment because of underpinning risk management in sukuk structures. Also, essential social amenities in many might suffer decay not only because it is capital intensive but also because its public interest and not mainly for profit making. Hence, Sukuk investment is a vibrant Islamic financing for social amenities (COMCEC, 2018). Apart from the fact that sukuk is an equitable financing for capital projects, sukuk investment has the potential of increasing financial inclusion among the Muslims who are willing to finance project that are compliant to shariah unlike mere sales of bonds that usually not back any project rather creation of money that might have negative economic consequences during recession (AbdulKareem \& \& Mohd Sadad, 2019).

\section{How Can Sukuk Help Nigeria Infrastructural Development?}

Sukuk can help Nigerian states in a way that traditional bonds (or debt) cannot. The FGN has been struggling with the diversification of the economy away from crude oil exports to non-oil revenues in recent years. The challenge is partly as a result of seepages in the system and poor infrastructure that will promote MSME and attract direct foreign investment in the country.

\section{Benefits of SUKUK in Nigeria}

According to the Securities and Exchange Commissions, the following are the benefits of sukuks in Nigeria as she try to develop her infrastructure.

- Domestic issuer (sovereigns and corporations) can use Sukuk instrument to tap funding from international market with huge investor base and thereby attracting direct foreign investment (DFI).

- Issuance of Sukuk can attract domestic investment capital which is invested according to Islamic principles.

- Sukuk, as an investment product, appeal to faith-based investors as well as conventional investors who are seeking liquid, diversified and attractively priced instruments with stable returns

- Sukuk ensures that every financial activity is backed by real economic activity and thus promotes financial stability and real economic development.

- Sukuk as investible product serves as liquidity management tool for banks and other Islamic financial institution.

- The tradable nature of Sukuk enables investors to liquidate their investments with ease whenever the need arises and as a result, enhances market liquidity

- Sukuk investment is relatively free from default risk

- Income from Sukuk investment is tax-free in advance markets

- Sukuk certificate qualify as collateral for interest-free borrowing

- Sukuk pricing is competitive in relation to other financing mode

- Low cost financing because it carries no burden of debt

- Sukuk, as an asset class, provides an alternative investment opportunity for the ethically conscious populace and otherwise

- Sukuk provides an alternative source of funding developmental and expansion projects

- When project-based, Sukuk can generate jobs. 
Volume 3 Issue 7 (June 2021) PP. 104-113

DOI 10.35631/AIJBAF.37009

- Issuance of Sukuk deepens the domestic bond market in order to promote economic growth

- Sukuk structures mandate accountability to finance providers, thus it will promote better governance on corporate and institutional levels

- Investment in Sukuk has a social and an ethical benefit to the wider society beyond "pure return"

https://sec.gov.ng/investor-education/sukuk-islamic-bond-at-a-glance/

\section{What are the Growth Potentials of the Nigerian Sukuk Market?}

Nigeria with population of about 201 million (Sources include: World Bank, United States Census Bureau) and a significant Muslim population estimated at over 50\%, Nigeria has more Muslims than all the major Sukuk issuers like Saudi Arabia, Malaysia, , UAE, Qatar and Kuwait put together.

Nigeria is estimated as the largest economy in Africa with a Gross Domestic Product of about $\$ 510$ billion, has a larger economy than all the major issuers except Saudi-Arabia.

\section{Who are the Participants in the Nigerian Sukuk Market?}

Generally, participants in the Sukuk market in Nigeria include:

Sovereigns: The Debt Management office formation (DMO in October 2000). The need for the creation of a separate public debt management office was therefore aimed at achieving the following advantages:

Good debt management practices that make positive impact on economic growth and national development, particularly in reducing debt stock and cost of public debt servicing in a manner that saves resources for investment in poverty reduction programs;

Prudently raising financing to fund government deficits at affordable costs and manageable risks in the medium- and long-term;

Achieving positive impact on overall macroeconomic management, including monetary and fiscal policies;

Consciously avoiding debt crisis and achieving an orderly growth and development of the national economy;

Improving the nation's borrowing capacity and its ability to manage debt efficiently in promoting economic growth and national development;

Projecting and promoting a good image of Nigeria as a disciplined and organized nation, capable of managing its assets and liabilities;

Providing opportunity for professionalism and good practice in nation building; https://www.dmo.gov.ng/about-dmo 


\section{Structure of the Federal Government of Nigeria Sukuk Issuance}

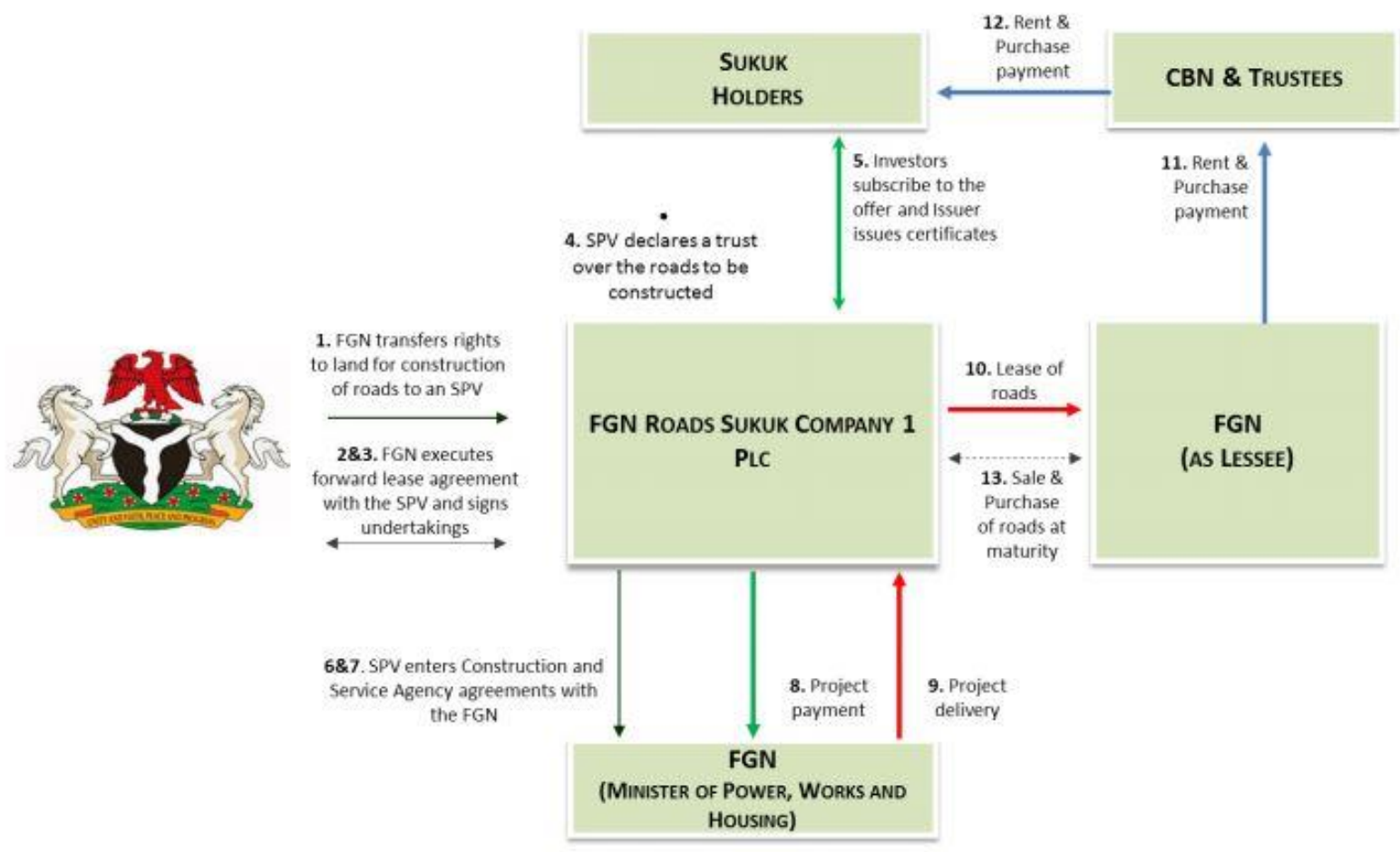

Source: Debt Management Office of Nigeria website

\section{Reference}

AbdulKareem, I. A., \& \& Mohd Sadad Bin Mahmud. (2019). Infrastructure Project Financing Through Sukuk as an Alternative to Infrastructure Project Financing Through Sukuk as an Alternative to Conventional Bond Financing. Journal of Management and Operation Research, 1(19), 1-11.

Adenike, T. (2018). Poverty and Unemployment Paradox in Nigeria Poverty and Unemployment Paradox in Nigeria . IOSR Journal Of Humanities And Social Science (IOSR-JHSS), 19(5), 106-116. https://doi.org/10.9790/0837-1954106116

Agbigbe, W. A. (2016). The Impact of Transportation Infrastructure on Nigeria's Economic Developmeny. Walden University.

Ahmed, H., Lane, M. H., \& Dh, D. (2018). CONTRIBUTION OF ISLAMIC FINANCE TO THE 2030 AGENDA FOR SUSTAINABLE DEVELOPMENT.

Ali, S. S. (2005). Islamic Capital Market Products : Developments and Challenges.

Beebee Salma Sairally, Farrukh Habib, Hafas Furqani, Hissam kamal Hassan, Marjan Muhammad, Muhammad Zakariya Othman, Mohd Bahroddin Badri, Najeeb Zada, Shabana M. Hasan, Y. A. A.-B. (2017). Șukūk Principles \& Practices. (B. S. S. \& M. Muhammad, Ed.) (1st ed.). Kuala Lumpur, Malaysia: International Shariah Research Academy for Islamic Finance.

Busari, S. A. (2018). Adequacy of Regulation and Supervision in Default Sukuk:Juristic Analysis of Cases in Malaysia, USA \& UAE. Kuala Lumpur, Malaysia: IIUM Library.

Chete, L. N., Adeoti, J. O., Adeyinka, F. M., \& Ogundele, O. (2016). Industrial development and growth in Nigeria: Lessons and challenges. 
Volume 3 Issue 7 (June 2021) PP. 104-113

DOI 10.35631/AIJBAF.37009

COMCEC. (2018). The Role of Sukuk in Islamic Capital Markets. Committee for Economic and Commcercial Cooperation of the Organization of islamic Cooperation. Ankara, Turkey: The COMCEC Coordination Office. Retrieved from http://ebook.comcec.org/Kutuphane/Icerik/Yayinlar/Analitik_Calismalar/Mali_Isbirli gi/Toplanti10/files/assets/common/downloads/publication.pdf

https://sec.gov.ng/investor-education/sukuk-islamic-bond-at-a-glance/

https://www.dmo.gov.ng/about-dmo

Khiyar, K. A. (2020). Malaysia: 30 Years of Islamic Banking Experience (1983-2012). International Business \& Economics Research Journal -, 11(10), 1133-1146.

Lagos Chamber of Commerce \& Industry. (2016). Looking beyond Oil. Lagos. Retrieved from https://www.pwc.com/ng/en/assets/pdf/nigeria-looking-beyond-oil-report.pdf

Ogbuagu, U. R., Ubi, P. S., \& Effiom, L. (2014). Corruption and Infrastructural Decay: Perceptible Evidence from Nigeria Corruption and Infrastructural Decay : Perceptible Evidence from. Journal of Economics and Sustainable Development ISSN, 5(10), 1-10.

Ogun, T. P. (2010). Infrastructure and Poverty Reduction Implications for Urban Development in Nigeria. Ile Ife.

Oxford Business Group. (2019, April 25). Nigeria's appeal to investors for infrastructure development. Country Report. Retrieved from https://oxfordbusinessgroup.com/news/nigeria's-appeal-investors-infrastructuredevelopment

Popova, Y. (2013). TRANSPORT INFRASTRUCTURE AS AN INTENSIFIER OF SOCIAL DEVELOPMENT OF THE REGION. In "Reliability and Statistics in Transportation and Communication (pp. 134-142).

Rufus, B. (2017). Critical Infrastructure Decay and Development Crises in Nigeria. Global Journal of HUMAN-SOCIAL SCIENCE: F Political Science, 17(2), 2-9.

Sukuk Markets A Proposed Approach for Development Ketut Ariadi Kusuma Anderson Caputo Silva, 2014 world Bank Global practice group

Zainab Ahmad. (2019, October 27). Nigeria: Zainab Ahmed - U.S.\$3 Billion World Bank Loan to Solve Nigeria's Two Critical Power Problems. Allafrica. Retrieved from https://allafrica.com/stories/201910270126.html 